\title{
Leadership in Planning and Budgeting on Higher Education
}

\author{
Yahya \\ yahya_tambunan@yahoo.com
}

\author{
Kasman Rukun
}

\begin{abstract}
Planning and budgeting are routine activities in a university to achieve its vision and mission made by the leaders as annual programs and five yearly activities. Rector of the University Tanjungpura (UNTAN), during the Occupation 20112015 has a vision "In 2020 UNTAN will be preservation institutions and scientific information center of West Kalimantan and produces human resource with the moral of Pancasila and able to compete at local, national, regional, and international levels. As an elaboration of the vision and mission, rector of UNTAN in 2013 has made a policy direction on three pillars, namely (1) Equity and access expansion (2). Improving the quality, relevance and competitiveness (3), strengthening governance, accountability and public image. This policy is elaborated into 12 strategic target programs with 46 indicators activities and total cost of Rp. $425,680,326,000$. Based on the research findings, it showed that: a) The vision and mission of the rector is not fully reflected in the vision and mission of faculties, departments and study programs; b) the budget absorption of UNTAN within last five years tended to decline, the year 2010: $95.78 \%, 2011: 96.18 \%$, 2012: $93.70 \%$, 2013: $94.30 \%$, and 2014 ie: $92.86 \%$. The study recommends that the leadership of the UNTAN does not effectively carry out budgeting planning and leadership to support the entire program in order to achieve the vision goes well.
\end{abstract}

Keywords - strategy, leadership, vision, mission and program budgeting.

\section{INTRODUCTION}

The main function of leadership in higher education is to determine the university's direction or vision and aim to achieve them within a certain period time. The strategy to achieve the vision should be ideally reflected in planning activities and budgets divided into organizational units. Although the direction or vision is very different from planning, however planning is a management process to achieve the goal (Kotter, 1990). The most common period of achieving the vision of the university is five years of work set out in the strategic plan of the university; the plan was later realized into the annual operating plan. The university's annual program plan for the next five years typically have provided a clear picture of how much fund and the time required to achieve the vision that is calculated based on the available sources. Similarly, the annual event is usually associated with the funds available. The entire planned program and activities theoretically should support the vision and mission and objectives that have been made by the university management.

Rector of the University Tanjungpura (UNTAN), during the Occupation 2011-2015 had a vision that is "In 2020
UNTAN will be preservation university and scientific information center of West Kalimantan and produce human resource with the moral of Pancasila and able to compete at local, national, regional, and international levels. While its mission is to "Provide qualified education, research and community service to produce outcomes that are able to follow, develop and advance the science, technology and art as well as providing direction for the development in accordance with their respective science".

As the leadership of the college, rector through Committing Officer (CO), bureau of planning and financial managers as well as units under the program should know what should be made to achieve the vision and mission of the rector. In the middle of time, the leaders must also make sure that the goals that have been shared out within the activities and the budget available and sufficient time. This study aims to reveal how the rector's leadership strategy in the planning and budgeting process to achieve its vision and mission.

\section{Methodology of AnAlysis}

This study used a qualitative approach. According Poerwandari (1998) Qualitative research is research that produce and process the descriptive data, obtained through interviews, field notes, pictures, photo video recording and others.

This research emphasizes the closeness to the people and the research to the situations, so that researchers gain a clear understanding of reality and real life conditions, and for the specified purpose:

Respondents are implementing the budget associated with achieving the vision and mission of the rector of the Vice Rector II, head of Bureau, dean and head of department at the Tanjungpura University.

In the study, there are two stages of the research, namely: Preparatory Phase Research, First researchers made the interview guides prepared based on the meaningfulness of life dimension in accordance with the problems faced by the subject. This interview guidelines contained fundamental questions that will be developed in the interview. The interview guidelines that had been developed were showed to an expert in this case is research advisor to obtain input regarding the content of the guidelines interview.

Researchers looked for subjects that correspond to the characteristics of the study. The interviews were conducted after asking for the readiness of the subject to be interviewed. Once the subjects were willing to be interviewed, the 
researchers made a deal with the subject of the time and the place to conduct the interviews.

In this research, researchers used three data collection techniques, i.e. interviews, observation, and document analysis. 1) Interviews were conducted with respondents related to the research questions and sometimes develop in accordance with the information needed. 2) Observations were conducted on the subject, the subject's behavior during the interview, the interaction of the subject with the researcher and the things that were considered relevant so as to give-the additional data on the results of interviews. 3) Analysis of the document is to see and interpret documents associated with the planning and budgeting process in achieving the objectives of the institution.

Data analysis was the process of preparing or processing the data to be interpreted further. New data from observations to UNTAN should be analyzed first by using qualitative data analysis in order to know the meaning of observation, interviews and documentation study were done by arranging the data, linking data, reduce data, presentation of data and draw conclusions/verification, where the process took place circularly during the study. Since the beginning of the study the researchers have already started with the search for the meaning of the patterns of behavior of the actors, explanations, confirmations are possible, and noted the groove causal regularity.

In the early stages of data collection, the focus of researchers was widespread and not clear yet, the observation was still general and widespread. After focusing more clearly the researchers used a more structured observation to obtain more specific data. Based on the above reasoning, the researchers used the model of Miles and Huberman (1992: 73), like Figure 1 below:

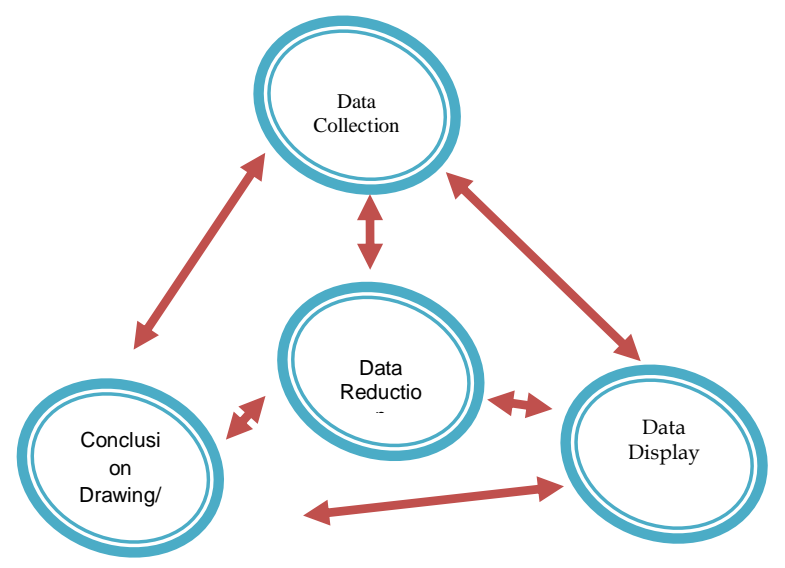

Figure 1. Components and Data Analysis Model

\section{RESULTS AND DISCUSSION}

As the vision and mission descriptions rector in 2013 UNTAN has made a policy direction on three pillars, namely (1) Equity and Expanding Access (2). Improving the quality, relevance and competitiveness (3). Strengthening governance, accountability and public image. This policy program was elaborated into 12 strategic targets with 46 indicators of the performance of activities with a total cost of $\mathrm{Rp}$. $425,680,326,000$. These budgets will be distributed in the form of money and activity in nine faculties, one graduate program and 52 courses and 25830 students. After 7 times the amandement of UNTAN real budget was Rp. $400,709,808,000$, and the absorbed at end of the year was Rp. $380,439,660,064$, with the level of achievement was $92.86 \%$. When compared with the budget absorption UNTAN last five years are likely tended to decline, the in the year 2010: 95.78\%, 2011: 96.18\%, 2012: 93.70\%, 2013: 94.30\%, and in 2014 i.e.: 92.86\%. This reinforces the opinion of Rien Pantekostani in PMIS Journal of UNTAN-PSIAN-2013, which says that the performance UNTAN tended to be not good yet. The strategic goal simplified look like the following table.

Table 1. Strategic Objectives UNTAN Year 2013

\begin{tabular}{|c|c|}
\hline \multicolumn{2}{|r|}{ Strategic target } \\
\hline 1 & Competence Enhancement Teaching Staff \\
\hline 2 & $\begin{array}{l}\text { Improving motivation Lecturer / Student 's competition research and } \\
\text { service }\end{array}$ \\
\hline 3 & Financial Management Improvement to the management of one door \\
\hline 4 & $\begin{array}{l}\text { Optimizing the utilization of Information Technology ( ICT ) as a } \\
\text { medium of learning }\end{array}$ \\
\hline 5 & Developing and Optimizing the utilization of Laboratory \\
\hline 6 & $\begin{array}{l}\text { Developing and Optimizing the utilization of facilities and } \\
\text { infrastructure }\end{array}$ \\
\hline 7 & optimizing the utilization of the Library \\
\hline 8 & Increasing Role and Function of Academic Quality Assurance \\
\hline 9 & $\begin{array}{l}\text { Optimizing the Institutional Autonomy Principle Both the Academic } \\
\text { and Non Academic Affairs }\end{array}$ \\
\hline 10 & Management Improvement Scholarships \\
\hline 11 & $\begin{array}{l}\text { Speeding The Study and Preparing Graduates Entering the Market } \\
\text { working }\end{array}$ \\
\hline 12 & Revitalization Learning Systems oriented to Problem Based Learning \\
\hline
\end{tabular}

The application of Performance-based budget plan in particular, at UNTAN was also based on the Guidelines for Planning and Budgeting Reform (2009), there are some the main elements that need to be determined in advance that vision and mission, goals, objectives, programs and activities. UNTAN's vision refers to what will be achieved in the long term while the mission is a framework that describes how the vision will be achieved. Interest is a further elaboration of the vision and mission. The purposes of UNTAN are described in the National Medium Term Development Plan which show stages that must be passed in order to achieve the vision and mission that has been set. Interest UNTAN illustrates a clear direction as well as realistic challenge. The purposes of UNTAN are characterized by providing an overview of key services, clearly illustrates the direction of the organization and its programs, challenging but realistic, identifies the object to be served as well as what will be achieved. Goals, describe specific measures to achieve the objective and measurable. Goals have been made in helping policy budget of UNTAN to achieve the goal by setting specific targets and measurable. Criteria for good target is done using specific criteria, 
measurable, achievable, relevant, and had time limit (specific, measurable, achievable, relevant, timely / SMART) and the important one that the goals will have to support the aims (supporting goal), The program is a set of activities that will be implemented as part of efforts to achieve the series of goals and objectives. UNTAN's programs have been divided into activity and should have been accompanied by a target output and outcome. The program has been created is linked to the goals and objectives as well as rational and achievable. Activities. Event is a series of services that is intended to produce outputs and outcomes that are important to the achievement of the program. In preparing the budget based on performance, organization or an organizational unit is not only required to prepare a budget on the basis of functions, programs, activities and types of expenditure but also set the performance to be achieved. The performance, among others in the form of output (output) of the activities to be undertaken and the results (outcomes) of the program that has been set. UNTAN has set achievement (performance) to be achieved, and then calculated the funding required to produce output or targeted results according to plan performance.

Vision and mission of the rector of UNTAN enshrined in the strategic plan to give wise expectations to the development of education and science in particular "preservation" is understood as the preservation of an object, either by treating and rebuilding the object, both environments such as forests of Borneo and culture from being damaged or disappear altogether. For this noble purpose has made several targeted programs.

Head of the Administrative Bureau of Planning and Information Systems said that "recently there is a revision of the strategic plan targets UNTAN in support of Higher Education Strategic Plan 2010-2014. Of the 28 planned strategic objectives from 2013 was simplified into 12 strategic objectives to meet five strategic objectives as a referral made by the Higher Education system by the Directorate General of Higher Education 1. Effective and efficient system 2. Availability of qualified and relevant higher education in Indonesia 3. Equality and assuredness access to higher education 4. Realizing universities are autonomous and accountable 5. Interaction with the community college that reflects the interrelationships are aligned and mutually beneficial".

Statement "Preservation and scientific information center at the rector's vision and objectives for strategic simplified from 28 to 12 point (table below) is not effectively socialized to the leadership underneath, so that faculties and departments is not up to follow this step. Faculty of forestry for example premises vision "In the year 2020 will become a faculty that excels in assessment and development of forestry sciences that benefit the development and welfare of the public and professionals to produce graduates who are able to compete nationally and internationally". This vision is supported 27 strategic objectives with a budget of Rp 869.67 million, (less than 1 billion excluding salaries) with 786 students. Then the faculty of Mathematics with a vision "To be the developer institution of the exact sciences and produce graduates MIPA with noble character and able to compete in local, national and international levels" described in 10 strategic objectives and support a budget of Rp. 8.723675 billion, with 1316 students. The vision and mission of the rector yet fully reflected in the vision and mission of the faculty, especially majors and study programs that exist both as a derivative concept and use of the budget. It was different from what is proposed by Sosik (2007) that a leader's personality can interact with his or her behavior to help shape vision content...... that leaders are often self-expressive of who they are in their communications, and such expressiveness needs to be consistent with their behavior to produce the vision statements that are authentic to their true selves.

The amount of budget available and distributed to group activities as well as its achievement level looks like the following table.

Table 2. Level of Accomplishment Strategic Objectives

\begin{tabular}{|c|c|c|c|}
\hline \multicolumn{2}{|r|}{ Strategic target } & \multirow{2}{*}{$\begin{array}{c}\begin{array}{c}\text { Budget } \\
\text { performance } \\
\text { in Million } \\
\text { Rupiah }\end{array} \\
1.881 .871\end{array}$} & \multirow{2}{*}{$\begin{array}{c}\begin{array}{c}\text { level of } \\
\text { achievement }\end{array} \\
0\end{array}$} \\
\hline 1 & $\begin{array}{l}\text { Competence Enhancement } \\
\text { Teaching Staff }\end{array}$ & & \\
\hline 2 & $\begin{array}{l}\text { improving motivation Lecturer / } \\
\text { Student 's competition research } \\
\text { and service }\end{array}$ & 7.214 .270 & 95.987 \\
\hline 3 & $\begin{array}{l}\text { Financial Management } \\
\text { Improvement to the management } \\
\text { of one door }\end{array}$ & 258.472 .432 & 95.99 \\
\hline 4 & $\begin{array}{l}\text { Optimizing the utilization of } \\
\text { Information Technology ( ICT ) } \\
\text { as a medium of learning }\end{array}$ & 4.152 .504 & 77.28 \\
\hline 5 & $\begin{array}{l}\text { Developing and Optimizing the } \\
\text { utilization of Laboratory }\end{array}$ & 44.552 .000 & 97.825 \\
\hline 6 & $\begin{array}{l}\text { Developing and Optimizing the } \\
\text { utilization of facilities and } \\
\text { infrastructure }\end{array}$ & 36.319 .059 & 95.504 \\
\hline 7 & $\begin{array}{l}\text { optimizing the utilization of the } \\
\text { Library }\end{array}$ & 1.229 .809 & 89.02 \\
\hline 8 & $\begin{array}{l}\text { Increasing Role and Function of } \\
\text { Academic Quality Assurance }\end{array}$ & 47.995 .493 & 75.368 \\
\hline 9 & $\begin{array}{l}\text { Optimizing the Institutional } \\
\text { Autonomy Principle Both the } \\
\text { Academic and Non Academic } \\
\text { Affairs }\end{array}$ & 351.952 & 85.88 \\
\hline 10 & $\begin{array}{l}\text { Management Improvement } \\
\text { Scholarships }\end{array}$ & 645.200 & 100 \\
\hline 11 & $\begin{array}{l}\text { Speeding The Study and } \\
\text { Preparing Graduates Entering the } \\
\text { Market working }\end{array}$ & 8.816 .608 & 99.89 \\
\hline 12 & $\begin{array}{l}\text { Revitalization Learning Systems } \\
\text { oriented to Problem Based } \\
\text { Learning }\end{array}$ & 500.000 & 91,55 \\
\hline & Total & 409.709 .808 & 92.86 \\
\hline
\end{tabular}

Nevertheless Budget Plan Organization (RAKL) set by the Department of Education and Culture was binding and uniting the programs and activities based on the budget lines of code that will be made by each unit ranging from the rector, faculty and department. Although binding, in fact it can be incorporated in the form of theme activities towards achieving the vision of the leadership. 
Jamaludin as head of the Bureau of Administration and General said that the program is based on the code budget program formatted by the Department of Education \& Culture, verily has limited the activities planned by each unit at the university, so that the program and planned activities of each faculty is relatively the same. In contrast to the budget and finance for manager it's advantageous because it is easier to control.

\section{CONCLUSION}

Based on the information, data, and descriptions that have been described above, it can be concluded that the Rector of Tanjungpura University was not maximal yet to implement the strategy of leadership in planning budgeting to achieve its vision and mission. It is seen that there are programs and activities either at the university, faculty or department which does not show the elaboration to the vision and mission of the rector.

\section{REFERENCES}

[1] BPKP, 2005. Pedoman Penyusunan Anggaran Berbasis Kinerja. Jakarta.

[2] Burhanudin, 2002. Pengaruh Karakteristik Anggaran Terhadap Efektifitas Pelaksanaan Anggaran (Studi di Kota Malang). Tesis, tidak dipublikasikan. PPS Universitas Brawijaya. Malang.

[3] Bratakusuma, Dedy Supriyadi. 2001. Otonomi Penyelenggaraan Pemerintahan Daerah. Gramedia. Jakarta

[4] Devas, Nick et all, 1989. Keuangan Pemerintah Daerah di Indonesia, UIPress, Jakarta, 1989

[5] Domai, Tjahjanulin. 2002. Reinventing Keuangan Daerah (studi tentang pengelolaan keuangan daerah). Dalam Jurnal Administrasi Negara VolumeII Nomor 2 Maret 2002. FIA Universitas Brawijaya.

[6] Faisal, Sanapiah, 1992. Penelitian Kualitatif: Dasar-dasar dan Aplikasi, Y3A, Malang

[7] Fauzi, Achmad dan Ek. Iskandar, 1995. Cara Membaca APBD, PT Danar Wijaya Brawijaya University Press, Malang.

[8] Hendrarso, E.S. 2005. Penelitian Kualitatif: Suatu Pengantar, dalam Metode Penelitian Sosial: Berbagai Alternatif Pendekatan, editor: Bagong Suyanto, Penerbit Kencana. Jakarta

[9] Ichsan, Moch, dkk, 1997. Administrasi Keuangan daerah: Pengelolaan dan Penyusunan APBD, PT. Danar Wijaya, Brawijaya University Press, Malang.

[10] Indonesia Review, 2006. Penyusunan Anggaran Harus Berbasis Kinerja.www.indonesiareview.com, 31 Maret 2006.

[11] Kaho, Josef Riwu, 2002. Prospek Otonomi daerah di Republik Indonesia, Rajawali Press, Jakarta.

[12] Mardiasmo, 2001. Manajemen Penerimaan Daerah, Pengeluaran Daerah \& Bentuk seta Struktur APBD 2001. Disampaikan pada Workshop Pembekalan Penyusunan Propeda Kabupaten/ Kota Propinsi NTB, bekerjasama dengan SIAGA Project dan Bappeda Mataram.

[13] Mardiasmo, 2001. Perencanaan Keuangan Publik Sebagai Suatu Tuntutan dalam Pelaksanaan Pemerintahan Daerah yang Bersih dan Berwibawa. Makalah disampaikan dalam acara Diskusi Panel Nasional yang diselenggarakan oleh IAI-KASP, tanggal 22 Maret 2001 di Jakarta.

[14] Mardiasmo, 2002, Akuntansi Sektor Publik, Yogyakarta, Penerbit ANDI,

[15] Mardiasmo, 2002. Otonomi dan Manajemen Keuangan Daerah, Penerbit ANDI Yogyakarta.

[16] Miles, M. B. \& Hubberman, M. A, 1992. Qualitative Data Analisys, Sage Publication Inc. UK

[17] Moleong, Lexy, 2000. Metode Penelitian Kualitatif. Bandung, PT Remaja Rosda Karya.
[18] Nugroho, Riant. D, 2001. Reinventing Indonesia, Menata Ulang Manajemen Pemerintah untuk membangun Indonesia Baru dengan Keunggulan Global, Makalah.

[19] Nugroho, Trilaksono, 2000. Reformasi dan Reorientasi Kebijakan Otonomi daerah dalam Perspektif Hubungan Pemerintah Pusat-daerah, Jurnal Administrasi Negara, Vol. 1 2000, FIA-Unibraw Malang.

[20] Nugroho, Trilaksono. 2003. Administrasi Keuangan Negara. FIA Universitas Brawijaya. Malang.

[21] Pahlawi, Riza. 2002. Pengaruh Koordinasi Penyusunan Anggaran Terhadap efektifitas Pelaksanaan Anggaran (Studi pada Pemerintah Propinsi Sumatera Selatan). Tesis, tidak dipublikasikan. PPS Universitas Brawijaya. Malang.

[22] Prihantoro, Purwono, 2001, Pembangunan Daerah, Renstra dan Akuntabilitas (Pendekatan Public sector Balanced Scorecard), 2001.

[23] Sidik, Mokhamad. 2004. Proses Penyusunan Anggaran Kinerja (Studi di Pemerintah Kota Blitar). Tesis, tidak dipublikasikan. PPS Universitas Brawijaya. Malang.

[24] Singarimbun, Masri \& Effendi, Sofyan, 1985. Metode Penelitian Survei. LP3ES. Jakarta

[25] Sosik ,J.J Sandi L. Dinger 2007. Relationships between leadership style and vision content: The moderating role of need for social approval, self-monitoring, and need for social power., The Leadership Quarterly 18 (2007) 134-153

[26] Tambunan, B.S, 1996. Perimbangan Keuangan Pusat dan daerah, Bina Rena Prawira, Jakarta.

[27] Undang-Undang nomor 17 Tahun 2003 tentang Keuangan Negara. 